\title{
The Economic Thresholds and Injury Levels for the English Grain Aphid, Sitobion avenae (F.) (Hemiptera- Aphididae) on Wheat Crop Ghanim, A. A. ${ }^{1}$; S. S. Awadalla ${ }^{1}$; F. E. Abd Allah ${ }^{2}$ and A. A. Abdel-Aziz ${ }^{2}$ ${ }^{1}$ Economic Entomology, Faculty of Agriculture, Mansoura University, Egypt. \\ ${ }^{2}$ Plant Protection Research Institute, Agriculture Research Center, Dokki, Egypt.
}

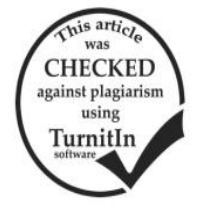

\section{ABSTRACT}

A yield loss $28.66,47.35,61.77$ and $79.86 \%$ caused due to introduce $1,3,5$ and 7 individuals/ spike of aphid species Sitobion avenea Fabricius (Hemiptera- Aphididae) as abundant wheat insect pests to fifteen tillers under cages. A market price of 2017 the wheat crop (420 E.L/Aradab) and costs of control measures 90 E.L/feddan was standard, during flowering and heading stage. The calculated economic injury level (EIL) and economic threshold (ETL) in average were 7.03 and 2.26 aphid/ spike/ feddan, respectively. Calculated gain threshold was 0.21 Ardab/feddan.

Keywords: Sitobion avenea; Feddan; Ardab $=150$ K.G

\section{INTRODUCTION}

Insect pests caused a great yield loss of wheat productions, where, cereal aphid only, caused yield reduction estimated by up to $23 \%$ (Tantawi, 1985). Thus, protection and expansion the productions of wheat, will be highly appreciated. Control wheat insects species insecticidal has many risks, like destruct of the balance between aphid and their natural enemies Smith et al., (1985) and El- Heneidy et al., 1991) and accelerated development of insecticide resistance in aphid species Shotkoski et al., (1990). So, integrate pest management (IPM) program, where, utilizes all available tools and techniques to avoid the insecticide hazards to the wheat crop and environment, was highly needed. Economic injury levels and economic thresholds are important components of a cost effective integrated pest management program and are useful for decision- making in the application of pesticides Larsson (1991).

Study response of the yield due to $S$. avenae infestations and their economic injury level and economic threshold were the aim of this paper.

\section{MATERIALS AND METHODS}

According to the methods of Ghanim and El-Adl (1983) and El-Serafi (1996), under of fifty metal cages with dimensions $(1 / 2 \mathrm{~m}$ wide $\times 1.5 \mathrm{~m}$ high $)$, covered with a muslin textile to avoid any invasion by other animals species rather than tested pest. Fifteen uninfected tillers to every ones cage before heading stage were used in the experimental, sown in the second half of December to synchronize with aphid species $S$. avenae peaks in April, using the commercial variety, Gemmiza11. Sitobion avenae collected awhile appears on wheat fields and carried to mass-rearing under laboratory conditions, Plant Protection Research Institute, Sakha Agriculture Research Station, and artificial re-infested tillers under cages, beginning Heading stage by $0,1,3$, 5 and 7 individuals/ tiller to every cage, respectively and repeated into three replicates. Cage plants unhand with normal agriculture practices and no insecticides were used until harvest. Every ones cage carried to laboratory awhile harvest, determined some yield components: whole, were removed spikes and counted per cage, counted the grains per ears and the weight of 1000 individual grains was considered. Aphox ${ }^{\circledR} 50 \%$ a water dispersible granule $(\mathrm{w} / \mathrm{w})$ pirimicarb, was estimated using the recommended aphicide, at the rate of $31.2 \mathrm{~g}$ $/ 100$ L. water. Calculation included the costs of control measures, 2017 market price of the crop and average 20 $\mathrm{ardab} /$ feddan. One feddan of wheat requires 400 litter water solution $+150 \mathrm{~g}$ of Aphox. Costs $=60$ L.E. + application expenses about 30 L.E. A total of costs were 90 L.E/feddan was considered in calculations.

To evaluate the damage of the artificial populations of $S$. avenae, injury level and economic threshold on wheat crop as follow:

Economic Injury Level (EIL) Calculation:

Economic Injury Level (EIL) the following parameters were estimated: rate of yield reduction, number of aphids, cost of aphid control procedures and market price of the crop. The generalized form of the EIL described by Pedigo et al. (1986) is:

\section{$\mathbf{E I L}=\boldsymbol{C} / \boldsymbol{V D} / \boldsymbol{K}$}

Where:

$C$ is the management cost per production unit (E.L/ Fed.), $V$ is market value per unit of production (E.L/ Ardab), $K$ is the proportional reduction in injury with control and $D^{\prime}$ is (D+I) into a single variable, $\mathrm{D}^{\prime}=$ percent yield loss per pest, or, the damage per unit injury (Ardab reduction/Fed./injury).

Economic Threshold Level (ETL) Calculation:

The formula used in estimating the economic threshold was cited after Wetzel (1995):

$$
\mathbf{E T L}=\mathbf{c c} / \mathbf{c p} \times \mathbf{1 0 0}
$$

Where:

$c c=$ Cost of implementing control measure. $\mathrm{cp}=$ Cost of the increasing rate of yield.

Yield loss: calculate according to the formula of Wetzel et al. (1980).

Where:

$$
y r=(y c-y t / y c) \times 100
$$

$\mathrm{yr}=$ Loss in the yield due to pests.

$\mathrm{yc}=$ The yield in control (in the absence of the insects)

$\mathrm{yt}=$ the yield in the presence of insects.

Gain threshold: (the amount of yield loss that constitutes minimum economic damage), and calculated according to Stone and Pedigo (1979) formula:

Gain threshold $=$ cost of pest control $/$ market price of wheat Ardab. Gain threshold $($ Ardab/Fed. $)=90 / 420=0.21$ Ardab $/$ Fed.

\section{RESULTS AND DISCUSSION}

The reduction of kernels yield, similes to the control summarized in Table (1), where, the high values of yield reflects the less damage of the re-infested certain aphid numbers. There was a negatively correlated between the yield (quantity and quality), where the high values of yield were 29.93 kernels per 
spike and $29.3 \mathrm{~g}$ weight of thousand kernels in control treatment, while, those values were decrease by every one aphid introduced to tested plot of a trial, whereby, introduced was 1. 3, 5 and 7 individuals/ tiller (spike) of aphid $S$. avenea. The values of kernels per spike were $16.72,14.95,12$ and 8.87 , respectively. The yield weight were 20.9, 15.4, 11.2 and 5.9 g/1000 kernels, respectively, where, introduce one individuals per tiller, caused the lowest reduce of yield $28.66 \%$ equal to 5.73 ardab/feddan. While, introduced seven individuals per spike caused of the high reduction of yield $79.86 \%$ equal to $15.97 \mathrm{ardab} /$ feddan.

The obtained results were agree with some authors i.e. Kolbe and linke (1974) in Germany, who determined the yield loss caused by 20-30 individuals, of cereal aphid species $S$. avenae, $R$. padi and $M$. dirhodum on winter wheat by $10 \%$ reduction, reached to $30 \%$ reduction, with increases of cereal aphids population to 150 individual per spike. They added that, cereal aphids control during flowering and spike stages increased the yield quantity. In Egypt, Ghanim and El-Adl (1983), determined the wheat yield loss caused by $M$ avenae was $40 \%$ and reported that the damaging role of $M$ avenae above the others of two species Rhopalosiphum padi Linneus, Schizaphis graminum Rondani. In Finland, Kurppa (1989) determined the yield loss caused by outbreak of aphid specie R.padi (20- 60 individual per tiller), synchronized with seedling emergence was $153 \mathrm{~kg} / \mathrm{ha}$. Infestation was decreased yield by a mean of $30 \mathrm{~kg} / \mathrm{ha}$ per day, and decreased to $41 \mathrm{~kg} / \mathrm{ha}$ per day when delayed. ElHeneidy et al. (2003) reported that, the stress of amassed cereal aphids $R$. padi and $S$. graminum caused of yield reduce to every specie and the two species together (21.2$75 \%, 21.3-80.8 \%$ and $22.2-84.2 \%$ ), respectively.

Table 1. Economic injury level, economic threshold level and wheat yield loss caused by the English grain aphid Sitobion avenea.

\begin{tabular}{lccccccc}
\hline $\begin{array}{l}\text { No. of } \\
\text { aphid/ tiller }\end{array}$ & $\begin{array}{c}\text { No. of } \\
\text { kernels/spike }\end{array}$ & $\begin{array}{c}\text { Weight of 1000 } \\
\text { kernels }\end{array}$ & $\begin{array}{c}\text { \% } \\
\text { Yield loss }\end{array}$ & $\begin{array}{c}\text { Yield loss } \\
\text { (ardab)/feddan }\end{array}$ & $\begin{array}{c}\text { Injury level } \\
\text { (ardab)/Aphid }\end{array}$ & EIL & ETL \\
\hline 0 & 29.93 & 29.3 & - & - & - & - & \\
1 & $16.72 \mathrm{a}$ & $20.9 \mathrm{a}$ & $28.66 \mathrm{~d}$ & $5.73 \mathrm{~d}$ & 0.114 & 6.56 & 3.80 \\
3 & $14.95 \mathrm{a}$ & $15.4 \mathrm{~b}$ & $47.35 \mathrm{c}$ & $11.19 \mathrm{c}$ & 0.053 & 8.54 & 2.26 \\
5 & $12.00 \mathrm{ab}$ & $11.2 \mathrm{c}$ & $61.77 \mathrm{~b}$ & $12.35 \mathrm{~b}$ & 0.049 & 7.08 & 1.73 \\
7 & $8.87 \mathrm{~b}$ & $5.9 \mathrm{~d}$ & $79.86 \mathrm{a}$ & $15.97 \mathrm{a}$ & 0.045 & 5.96 & 1.34 \\
\hline
\end{tabular}

There are no significant differences between the means with the same litters in the same column, according to Duncan Multiple Range Test at level of probability 0.05 .

The economic injury level is the lowest population density that will causes economic damage. Where, the economic damage is defined as the amount of injury that will justify the cost of pest control measures (Hoyt and Burts, 1974, Stern et al., 1959). The higher EIL reflects the more tolerance of wheat plants to the certain population of aphid specie, where the EIL calculated were 6.56, 8.54, 7.08 and 5.96 with average 7.03 aphid/ tiller/ feddan, when introduced (1, 3, 5 and 7aphid/ tiller), respectively.

Economic threshold was defined as the density at which control measures should be determined (e.g., biological control, cultural control, pesticide, etc.) to prevent an increasing pest population form reaching the economic injury level, (Stern, 1973). The Calculated ETL was 3.8, 2.26, 1.73 and 1.34 with average 2.26 aphid/ tiller/ feddan, when introduced (1, 3, 5 and 7aphid/ tiller), respectively, to enable the control decision makes avoided the insect population to prevent their population form reaching to economic injury level EL-Heneidy et al. (2003).

Calculated gain threshold (the amount of yield loss that constitutes minimum economic damage), where equals $90 / 420=0.21 \mathrm{Ardab} / \mathrm{feddan}$, this value approximately, equal the reduction $(0.23 \mathrm{ardab})$ of seven individuals, thus, seven individuals per spike was economic injury level of aphid species $S$. avenea on wheat plants during flowering and heading stage.

The obtained results agree with those obtained by Robert et al. (1985) in the USA, where, determined the ETLs of $S$. graminum on winter wheat were less than 10 individuals per plant. Larsson (1991) in Sweden, evaluated the ETLs of $S$. avenae and $R$. padi on winter wheat and barely, where, noticed the yield response to treatment significantly with more than 10 aphids/tiller. In Germany,
Wetzel (1995) found the injury level of $R$. padi and $M$. dirhodum were 10-15 individuals per spike on winter wheat.

While 3.5 individuals per ear was the ETL of aphid specie M. avanae. In addition, Li- Jiping et al. (1995) in China, noticed that the ETL for cereal aphids on wheat was 10 aphids/ plant at heading stage. El-Serafi (1996) in Germany, who determined EIL and ETL of $S$. avenae on wheat crop were 6.66 and 5 insect/ ear. El-Heneidy et al. (2003), in Egypt, determined the EIL values to cereal aphids $R$. padi and $S$. graminum and the two species together (6.47, 5.9 and 6.13 aphid/ tiller), respectively. While, it's ETL were (5.10, 4.41 and 4.39 aphid/tiller), respectively.

\section{REFERENCES}

El-Heneidy, A. H.; A. H. Ghannem; Y. H. Fayad and M. A. Shoeb (1991): Comparative population density of aphids and their natural enemies in wheat fields at Middle and Upper Egypt. In Annual Report of Nile Valley Regional Program on Cool Season. Food Legumes and Cereals, p.103-107, Giza, ARC-FCRI.

El-Heneidy, A.H., M.M. Ibraheem, H.E. Megahed, A.A. Attia, A.A. Magdy, W.M. Abdel-Awal and M.M. Hassan (2003): Assessment of economic injury and threshold levels for key cereal aphid species in Egyptian wheat regions. Bull. ent. Soc. Egypte, Economic Ser., 2003, 29: 43-56.

El-Serafi, H. A (1996): Studies on the economic threshold of some insect pests infesting certain cereal crops. Ph.D. Thesis, Fac.Agri. Mansoura Univ., Egypt. 174 pp.

Ghanim, A. A. and M. A. El-Adl (1983): Aphid population and damage to wheat plantation in Mansoura district, Egypt. J. Agric. Sci. Mansoura Univ., 8 (4):982-991. 
Hoyt, S. C. and E. C. Burts (1974): integrate control of fruit pests. Annu. Rev. Entomol. 18:259-280.

Kolbe, W. and W. Linke (1994): Studies of cereal aphids, their occurrence, effect on yield in relation to density levels and their control. Ann. App. Biol. 77:85-91.

Kuppa, S. (1989): damage and control of Rhopalosiphum padi L. in Finland during the outbreak of 1988. Annales Agriculturae Fennia., 28:349-370.

Larsson, H. (1991): Economic importance of cereal aphid s of different cost levels. Proceedings of $4^{\text {th }}$ Swedish Crop Protection Conference, Uppala, 30-31 January 1991.

Li-Jiping, Jin, Shelin; Hu, Guonfang; Wan, AnMing; Li, Jp; Jin, Sl; Hu, Gf. And Wan, Ann (1995): A preliminary study on population dynamics and economic threshold of wheat aphids in Gngy County, Gansu province. Plant Protection 21 (2):2-4.

Pedigo, L. P.; S. H. Hutchins and L.G. Highly (1986): Economic injury levels in theory and practice. Ann. Rev. Entomol. 31: 341-368.

Poston, F. L.; L. P. Pedigo, and S. M. Welch (1985): Economic injury levels: Reality and practicality. Bull. Entomol. Soc. Am. 29: 49-53.

Robert, L., D. Burton, K. Simon, J. Starks and M. Robert (1985): Seasonal damage by green bugs (Homoptera: Aphididae) to a resistant and a susceptible variety of wheat. J. Econ. Entomol., 78: 395-401.

Shotkoski F. A., Z. B. Mayo and L. L. Peters (1990): Indced disulfoton resistance in green bugs (Homoptera: Aphidiae). J. Econ. Entomol, $83: 2147-2152$.
Smith, R. G., T. L. Archer and E. D. Bynuni (1985): Lowrate applications of insecticides for green Homoptera: Aphidiae) control and effect on beneficial insects on sorghum. J. Econ. Entomol, 78:988-991.

Stern, V. M. (1973) Economic thresholds. Annu. Rev. Entomol. 18: 259-280.

Stone, J. D. and L.P. Pedigo (1979): Development and economic-injury level of the green clover-worm on soyabean in Iowa. J. Econ. Entomol., 65: 191-201.

Tantawi, A. M. (1985): Studies on wheat aphids in Egypt. II- Germplasm evaluation and crop loss assessment. RACHIS, 4(2): 26-27.

Vereijken, P.H., (1979): Feeding and multiplication of three cereal aphid species and their effect on yield of winter wheat. Agric. Res. Rep. (Versl. Landbouwk. Onderz.) 888, 53.

Wetzel, T. (1995): Getridblattlause in Pflanzenschutz und im Agrookosystem. Arch. Phytopath. Pflanz. 29: 437-469.

Wetzel, Th., B. Freir and W. Heyer (1980): Zur modellierung von Befall-Scadens-Relationen wichtiger Schadinsekten des Winterweizens. Z. Ang. Entomol. 89, 330-344.

\section{الحدود الإقتصاديه الحرجه ومستوى الضرر الإقتصادى لحشرة المن Sitobion avenae (رتبة متشابهة الأجنحه

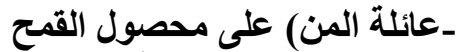

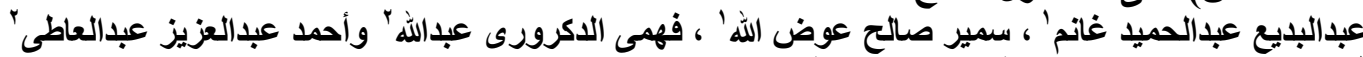

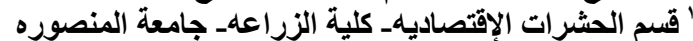

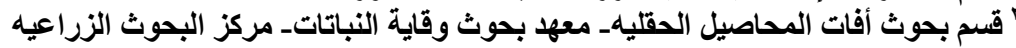

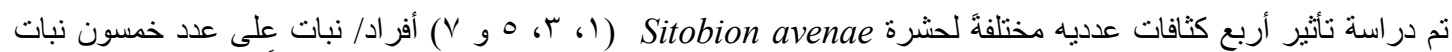

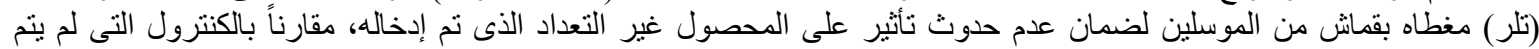

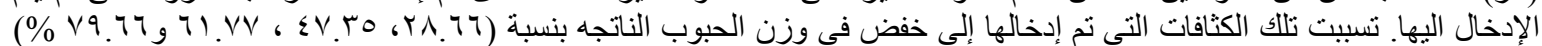

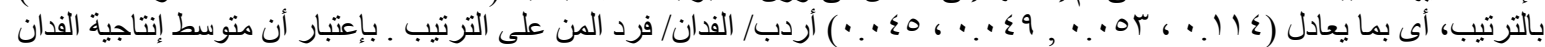

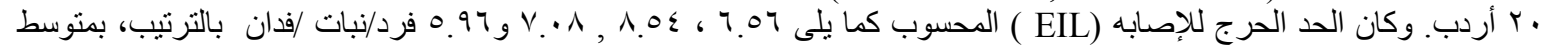

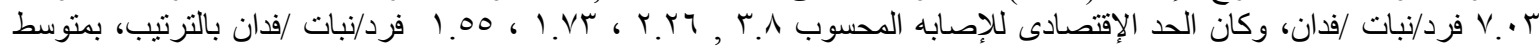
جr.ب فرد/نبات /فدان. وكذلك عند حساب حد المنفعة الإقتصاديه التى تعتبر نقطة بدايه وقوع الضرر الإقتصادى Gain threshold نجد

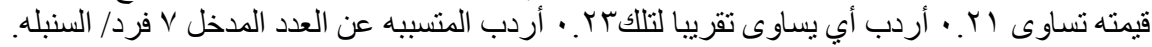

